DOI 10.22460/jpmi.v1i3.269-280

\title{
KEMAMPUAN PEMECAHAN MASALAH MATEMATIS SISWA SMP KELAS VIII PADA MATERI SISTEM PERSAMAAN LINEAR DUA VARIABEL DENGAN PENDEKATAN OPEN ENDED
}

\author{
Nuni Mulyowati ${ }^{1}$, M. Afrilianto ${ }^{2}$, Euis Eti Rohaeti ${ }^{3}$ \\ ${ }^{1,2,3}$ IKIP Siliwangi, Jl. Terusan Jenderal Sudirman, Cimahi, Jawa Barat, Indonesia \\ ${ }^{1}$ nunimulyowati04@ gmail.com, ${ }^{2}$ muhammadafrilianto@ikipsiliwangi.ac.id, ${ }^{3}$ e2rht@yahoo.com
}

Diterima: 21 Februari 2018; Disetujui: 28 Mei 2018

\begin{abstract}
The objective of this research is to analyze theimprovement of problem solving ability from students at VIII grade on material of two variables linear equationssystem thtough open ended approach. This research uses Classroom Action Reserch. The method of the research is descriptive. The research is conducted to VIII H grade student of SMP Negeri 9 in academic year 2017/ 2018 which consist of 40 students. The instrument is the testof students' mathematical problem solving ability, cycle test I and II after giving action. The result aspectof this research shows that the aspect of students' mathematical problemsolving ability increased, it can be seen from the result of the test, many studentsachive above beverage score (KKM). Bsed on indicator, it concludes that students' problem solving ability at VIII H grade of SMP Negeri 9on material of two variables linear equations system can be improved through open ended approach
\end{abstract}

Keywords: Problem Solving, Open Ended

\begin{abstract}
Abstrak
Penelitian ini bertujuan untuk menelaah kemampuan pemecahan masalah siswa Kelas VIII pada materi sistem persamaan linear dua variabel melalui pendekatan Open Ended. Jenis penelitian ini adalah penelitian tindakan kelas. Dengan mengggunakan metode kualitatif deskriptif. Penelitian ini dilaksanakan pada siswa Kelas VIII-H SMP Negeri 9 tahun pelajaran 2017/2018 dengan jumlah 40 orang. Instrumen yang di gunakan adalah tes kemampuan Pemecahan Masalah Matematis siswa, tes siklus I dan II setelah pembeberian tindakan. Hasil aspek penelitian ini menunjukkan bahwa aspek kemampuan pemecahan masalah matematis siswa mengalami peningkatan karena dari soal yang di ajukan dalam langkah tes, semakin banyak siswa yang memperoleh nilai di atas rata - rata (KMM). Berdasarkan indikator, disimpulkan bahwa kemampuan pemecahan masalah matematis siswa keas VIII-H SMP Negeri 9 pada materi system persamaan linier dua variable dapat ditingkatkan melalui pendekatan Open Ended
\end{abstract}

Kata Kunci: Pemecahan Masalah, Open Ended

How to cite: Mulyowati, N., Afrilianto, M., \& Rohaeti, E. E. (2018). Kemampuan Pemecahan Masalah Matematis Siswa SMP Kelas VIII pada Materi Sistem Persamaan Linear Dua Variabel dengan Pendekatan Open Ended. JPMI - Jurnal Pembelajaran Matematika Inovatif, 1 (3), 269-280.

\section{PENDAHULUAN}

Di Indonesia, pendidikan mendapat prioritas utama. Hal ini ditandai oleh usaha pemerintah dalam memberikan anggaran pendidikan sebanyak 20\% dari Anggaran Pendapatan dan 
Belanja Negara (APBN). Hal ini mengacu pada UUD 1945 pasal 31 ayat 1 yang menyebutkan bahwa setiap warga negara berhak mendapatkan pendidikan. Matematika merupakan bagian dari pendidikan dan dijadikan salah satu mata pelajaran wajib di sekolah. Salah satu kemampuan pada matematika ialah kemampuan pemecahan masalah (Hidayat \& Sariningsih, 2018).

Pemecahan masalah sebagai salah satu aspek kemampuan berpikir tingkat tinggi. National Council of Teachers of Mathematics atau NCTM (Fauziah, 2010) menyatakan bahwa standar matematika sekolah haruslah meliputi standar isi dan standar proses. Standar proses meliputi pemecahan masalah, penalaran dan pembuktian, keterkaitan, komunikasi, dan representasi. Sumarmo (Fauziah, 2010) menyatakan bahwa kemampuan-kemampuan itu disebut dengan daya matematik (mathematical power) atau keterampilan bermatematika (doing math). Salah satu doing math yang erat kaitannya dengan karakteristik matematika adalah kemampuan pemecahan masalah. Branca (Hendriana, Rohaeti, \& Sumarmo, 2017) menyatakan bahwa pemecahan masalah matematis meliputi metode, prosedur dan metode, prosedur dan strategi yang merupakan proses inti dan utama dalam kurikulum matematika atau merupakan tujuan umum pembelajaran matematika, bahkan sebagai jantungnya matematika. Beberapa indikator pemecahan masalah dapat diperhatikan dari paparan Sumarmo (Hendriana et al., 2017) yaitu :

a. Mengidentifikasi unsur-unsur yang diketahui, yang ditanyakan, dan kecukupan unsur yang diperlukan,

b. Merumuskan masalah matematika atau menyusun model matematika.

c. Menerapkan strategi untuk menyelesaikan berbagai masalah (sejenis dan masalah baru) dalam atau di luar matematika,

d. Menjelaskan atau menginterpretasikan hasil sesuai permasalahan asal, dan

e. Menggunakan matematika secara bermakna.

Kenyataan di lapangan menunjukkan bahwa kemampuan pemecahan masalah matematika siswa, khususnya siswa SMP, masih rendah. Laporan TIMMS tahun 1999 (Fauziah, 2010) menunjukkan kemampuan ssiswa SMP relatif lebih baik dalam menyelesaikan soal-soal tentang fakta dan prosedur. penalaran, kemampuan pemahaman dan kemampuan yang lain dengan baik serta mampu memanfaatkan kegunanaan matematika dalam kehidupan. Hasil studi Sumarmo (Anisa, 2014) berpendapat bahwa keterampilan menyelesaikan soal pemecahan masalah siswa sekolah menengah atas ataupun siswa sekolah menengah pertama masih rendah.

Berdasarkan masalah-masalah dan alternatif metode yang ada, peneliti akan mengambil sebuah judul "Analisis Kemampuan Pemecahan Masalah Matematis Siswa Kelas VIII SMP Negeri 9 pada Materi Sistem Persamaan Linear Dua Variabel dengan Pendekatan Open Ended". Tujuan penelitian ini yaitu untuk menelaah peningkatan kemampuan Pemecahan Masalah siswa Kelas VIII pada materi sistem persamaan linear dua variabel melalui pendekatan open ended.

\section{METODE}

Jenis penelitian ini adalah penelitian tindakan kelas (PTK) dengan menggunakan metode kualitatif deskriptif yang bertujuan untuk mendeskripsikan aktivitas guru dan siswa ketika dalam pembelajaran dan menelaah kemampuan Pemecahan Masalah siswa setelah melaksanakan pembelajaran dengan menggunakan pendekatan Open Ended. Penelitian 
tindakan kelas ini terdiri dari 2 (dua) siklus. Sampel penelitian yaitu pada siswa kelas VIII-H dengan jumlah siswa 40 orang di SMP Negeri 9 Cimahi Tahun akademik 2017-2018. Sebelum dilaksanakan tindakan, terlebih dahulu diberikan tes awal dengan maksud untuk mengetahui kemampuan awal siswa dan berkaitan dengan topik yang akan diajarkan yaitu persamaan linear dua variabel. Penelitian Tindakan Kelas dalam penelitian ini menggunakan model spiral yang dikembangkan oleh Kemmis (Mulhamah \& Putrawangsa, 2016). Setiap siklus terdiri dari perencanaan, tindakan, pengamatan, dan refleksi.

Data dalam penelitian ini didapatkan melalui observasi, dan tes. Masing-masing sumber data tersebut diperoleh dengan cara yang berbeda-beda disesuaikan dengan karakteristik data untuk mendapatkan kesimpulan yang valid (triangulasi).

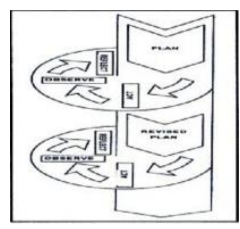

Gambar 1. Model penelitian tindakan Kemmis

Indikator tercapainya peningkatan kemampuan representasi matematika siswa pada penelitian ini merujuk pada:

a. Adanya pencapaian ketuntasan belajar minimal $80 \%$ dari jumlah seluruh siswa dan perolehan nilai minimal 7,00 secara perorangan.

b. Proses pelaksanaan pembelajaran berhasil apabila tindakan guru dan siswa mencapai $80 \%$ sesuai dengan rencana pelaksanaan pembelajaran.

\section{HASIL DAN PEMBAHASAN}

\section{Hasil}

\section{Tindakan Siklus I}

\section{Perencanaan}

Pada tahap ini hal-hal yang harus dilakukan adalah membuat rencana pelaksanaan pembelajaran (RPP) berdasarkan silabus yang menjadi acuan penelitian. RPP yang dibuat untuk siklus I terdiri dari dua pertemuan pada materi "persamaan linear dua variabel", dengan menggunakan pendekatan open ended. Setelah itu, peneliti melakukan pembentukan kelompok yang disesuaikan dengan pendekatan pembelajaran open ended. Karena jumlah siswa kelas VIII-H SMP Negeri 9 sebanyak 45 orang, maka kelompok yang dibentuk sebanyak 5 kelompok yang heterogen. Kemampuan pemecahan masalah matematis siswa yang di teliti pada penelitian ini melipui empat aspek, yaitu (1) memahami masalah; (2) membuat rencana pemecahan masalah; (3) melaksanakan rencana pemecahan masalah ; dan (4) menafsirkan solusi pemecahan masalah yang di peroleh. Nilai rata - rata tiap aspek , merancang perangkat evaluasi untuk tes siklus I.

\section{Pelaksanaan Tindakan}

Tindakan pembelajaran siklus I dilaksanakan dalam dua kali pertemuan yait u pada hari yang sama yaitu hari Rabu tanggal 15 November 2017, namun pada jam yang berbeda yaitu pada pukul 7.20-8.40 WIB dan pukul 13.00-14.25. Pembelajaran diawali dengan menyampaikan tujuan dan manfaat pembelajaran. Kemudian guru mengondisikan siswa terlebih dahulu agar 
siap untuk belajar. Setelah itu guru mengadakan apersepsi mengulang materi yang telah dipelajari.

Pada kegiatan inti, guru membagikan LKS kepada masing-masing kelompok. Ketika siswa mengerjakan LKS, guru berkeliling untuk membimbing jalannya diskusi dan membantu kelompok yang mengalami kesulitan.

Sehingga peneliti menilai bahwa pemecahan masalah matematis siswa meningkat pada pertemuan kedua. Selanjutnya pada akhir pembelajaran, guru dan siswa sama-sama menyimpulkan materi yang telah dipelajari. Kemudian guru, memberikan tes evaluasi siklus I dengan jumlah soal sebanyak 5 soal dan waktu mengerjakannya 40 menit. Setelah itu, guru menutup pembelajaran dengan salam dan berdoa. Setelah penyajian kelas kedua ini, guru dan peneliti mendiskusikan kekurangan yang terjadi dalam pembelajaran.

Selanjutnya peneliti mengingatkan bahwa pada siklus II nanti, pembelajaran matematika dengan menggunakan pendekatan open ended akan dikolaborasikan dengan penggunaan software geogebra. Hal tersebut diharapkan motivasi, minat dan kemampuan siswa pada siklus selanjutnya akan lebih meningkat dari sebelumnya. Dari hasil diskusi ini, guru bersedia untuk memperbaiki kekurangannya pada pertemuan pertama siklus II

\section{Observasi}

Pada tahap ini peneliti mengobservasi setiap pelaksanaan proses pembelajaran selama siklus I menggunakan lembar observasi. Hal-hal yang diobservasi meliputi cara guru dalam menyampaikan materi pelajaran yang sesuai dengan pendekatan pemecahan masalah dan sikap siswa selama mengikuti pelajaran. Hasil observasi terhadap guru dan siswa pada pertemuan pertama dan kedua dapat diuraikan sebagai berikut:

a. Guru kurang dapat menguasai kelas dan mengontrol siswa dalam kegiatan kelompok.

b. Guru kurang tegas dalam mengatur siswa yang tidak bersungguh-sungguh mengikuti pembelajaran.

c. Guru kurang memberikan motivasi.

d. Guru sudah memberikan penghargaan berupa tepuk tangan ketika siswa dapat menjawab atau menyelesaikan soal.

Tabel 1 Hasil Analisis Observasi Aktivitas Guru pada Pembelajaran Siklus I

\begin{tabular}{|c|c|c|c|c|}
\hline \multirow[b]{2}{*}{ No } & \multirow[b]{2}{*}{ Aspek } & \multicolumn{2}{|c|}{ Hasil Skor } & \multirow[b]{2}{*}{ Rata-rata } \\
\hline & & $\begin{array}{c}\text { Pertemuan } \\
1\end{array}$ & $\begin{array}{l}\text { Pertemuan } \\
2\end{array}$ & \\
\hline \multicolumn{5}{|c|}{ Pendahuluan } \\
\hline 1 & Guru menyampaikan tujuan pembelajaran & 4 & 4 & 3,5 \\
\hline 2 & Guru memotivasi siswa & 3 & 3 & 3 \\
\hline 3 & Guru mengadakan apersepsi & 3 & 3 & 3 \\
\hline 4 & $\begin{array}{l}\text { Guru mengondisikan siswa untuk siap } \\
\text { belajar }\end{array}$ & 4 & 3 & 3,5 \\
\hline \multicolumn{5}{|c|}{ Kegiatan Inti } \\
\hline 5 & $\begin{array}{l}\text { Guru membagi siswa dalam beberapa } \\
\text { kelompok }\end{array}$ & 5 & 5 & 5 \\
\hline 6 & $\begin{array}{l}\text { Guru membagikan LKS kepada masing- } \\
\text { masing kelompok }\end{array}$ & 5 & 5 & 5 \\
\hline
\end{tabular}




\begin{tabular}{|c|c|c|c|c|}
\hline \multirow[b]{2}{*}{ No } & \multirow[b]{2}{*}{ Aspek } & \multicolumn{2}{|c|}{ Hasil Skor } & \multirow[b]{2}{*}{ Rata-rata } \\
\hline & & $\begin{array}{l}\text { Pertemuan } \\
1\end{array}$ & $\begin{array}{l}\text { Pertemuan } \\
\quad 2\end{array}$ & \\
\hline 7 & $\begin{array}{l}\text { Guru membimbing siswa dalam } \\
\text { mengerjakan LKS }\end{array}$ & 4 & 4 & 4 \\
\hline 8 & $\begin{array}{l}\text { Guru meminta perwakilan kelompok untuk } \\
\text { presentasikan hasil kerja }\end{array}$ & 3 & 3 & 3 \\
\hline 9 & $\begin{array}{l}\text { guru meminta perwakilan kelompok } \\
\text { menyelesaikan soal latihan sebagai langkah } \\
\text { mempresentasikan soal ke dalam bentuk } \\
\text { tabel. }\end{array}$ & 2 & 3 & 3 \\
\hline 10 & $\begin{array}{l}\text { Guru memberikan penghargaan kepada } \\
\text { kelompok yang preseentasi dengan baik. }\end{array}$ & 3 & 3 & 3 \\
\hline \multicolumn{5}{|c|}{ Kegiatan Penutup } \\
\hline 11 & $\begin{array}{l}\text { Guru membimbing siswa untuk } \\
\text { menyimpulkan materi yang telah dipelajari }\end{array}$ & 4 & 4 & 4 \\
\hline 12 & $\begin{array}{l}\text { Guru memberikan tugas rumah dan } \\
\text { mengarahkan siswa untuk menyelesaikan } \\
\text { soal berdasarkan langkah-langkah yang } \\
\text { telah dipelajari. }\end{array}$ & 0 & 0 & 0 \\
\hline & $\begin{array}{c}\text { Jumlah } \\
\text { Presentase }\end{array}$ & & & $\begin{array}{c}40 \\
65 \%\end{array}$ \\
\hline
\end{tabular}

Berdasarkan Tabel 1, ketuntasan hasil observasi aktivitas guru pada proses pembelajaran mencapai $65 \%$. Hal ini menunjukkan bahwa indikator kerja dari segi proses belum tercapai yaitu minimal $80 \%$ proses pelaksanaan tindakan dilaksanakan sesuai dengan rencana pelaksanaan pembelajaran yang ditetapkan sehingga perlu dilakukan perbaikan pada siklus berikutnya. Sementara itu, hasil observasi terhadap aktivitas siswa menunjukkan hal-hal sebagai berikut:

a. Tidak semua siswa memperhatikan guru Siswa masih kurang dapat bekerjas secara tim.

b. Interaksi siswa dan siswa masih rendah dalam menyelesaikan tugas bersama

c. Siswa dalam kelompok dapat mempresentasikan hasil diskusinya di depan kelas, tetapi siswa dalam kelompok lain masih tidak memperhatikan jawaban kelompok temannya.

Tabel 2. Hasil Analisis Observasi Aktivitas Siswa pada Pembelajaran Siklus I

\begin{tabular}{|c|c|c|c|c|}
\hline \multirow[b]{2}{*}{ No } & \multirow[b]{2}{*}{ Aspek yang Dinilai } & \multicolumn{2}{|c|}{ Hasil Skor } & \multirow[b]{2}{*}{ Rata-rata } \\
\hline & & $\begin{array}{l}\text { Pertemuan } \\
1\end{array}$ & $\begin{array}{l}\text { Pertemuan } \\
\quad 2\end{array}$ & \\
\hline 1 & $\begin{array}{l}\text { Siswa mendengarkan dan memberikan } \\
\text { perhatian penuh pada penjelasan materi dan } \\
\text { tujuan pembelajaran }\end{array}$ & 3 & 4 & 3,5 \\
\hline 2 & $\begin{array}{l}\text { Siswa memperhatikan guru dalam } \\
\text { memberikan motivasi. }\end{array}$ & 3 & 3 & 3 \\
\hline 3 & $\begin{array}{l}\text { Siswa aktif memberikan respon dalam } \\
\text { kegiatan apersepsi }\end{array}$ & 3 & 4 & 3,5 \\
\hline 4 & Siswa aktif dalam kelompok ketika & 2 & 3 & 2,5 \\
\hline
\end{tabular}




\begin{tabular}{|c|c|c|c|c|}
\hline \multirow[b]{2}{*}{ No } & \multirow[b]{2}{*}{ Aspek yang Dinilai } & \multicolumn{2}{|c|}{ Hasil Skor } & \multirow[b]{2}{*}{ Rata-rata } \\
\hline & & $\begin{array}{c}\text { Pertemuan } \\
1 \\
\end{array}$ & $\begin{array}{c}\text { Pertemuan } \\
2 \\
\end{array}$ & \\
\hline & menyelesaikan soal LKS & & & \\
\hline 5 & Beberapa siswa senang belajar kelompok & 3 & 3 & 3 \\
\hline 6 & $\begin{array}{l}\text { Siswa mampu mengungkapkan pemikiran } \\
\text { tentang materi yang yang dipelajari. }\end{array}$ & 2 & 2 & 2 \\
\hline 7 & $\begin{array}{l}\text { Siswa dalam kelompok mampu } \\
\text { mempresentasikan hasil diskusi di depan } \\
\text { kelas }\end{array}$ & 3 & 3 & 3 \\
\hline 8 & $\begin{array}{l}\text { Siswa di kelompok lain aktif menanggapi } \\
\text { hasil pekerjaan temannya }\end{array}$ & 2 & 4 & 3 \\
\hline 9 & $\begin{array}{l}\text { Siswa mampu bertanya ketika mendapat } \\
\text { kesulitan }\end{array}$ & 4 & 4 & 4 \\
\hline 10 & $\begin{array}{l}\text { Dengan bimbingan guru, siswa } \\
\text { menyimpulkan pembelajaran }\end{array}$ & 4 & 4 & 4 \\
\hline & $\begin{array}{c}\text { Jumlah } \\
\text { Presentase }\end{array}$ & & & $\begin{array}{l}31,5 \\
63 \%\end{array}$ \\
\hline
\end{tabular}

Berdasarkan Tabel 2, ketuntasan hasil observasi aktivitas siswa pada proses pembelajaran mencapai $63 \%$. Hal ini menunjukkan bahwa indikator kerja dari segi proses belum tercapai yaitu minimal $80 \%$ proses pelaksanaan tindakan dilaksanakan sesuai dengan rencana pelaksanaan pembelajaran yang ditetapkan sehingga perlu dilakukan perbaikan pada siklus berikutnya.

\section{Evaluasi}

Setelah 2 kali pertemuan untuk menyelesaikan kompetensi dasar "Menyelesaikan persamaan linear dua variabel", dilaksanakan evaluasi tindakan siklus I pada tanggal 15 November 2017. Kegiatan ini dilakukan dengan tujuan untuk melihat sejauh mana materi pelajaran telah dikuasai siswa dan untuk melihat ketuntasan siswa dalam mengikuti pembelajaran matematika.

Tabel 3. Hasil Analisis Ketuntasan Belajar pada Pembelajaran Siklus I

\begin{tabular}{cccc}
\hline No & Ketuntasan & Jumlah & Presentase \\
\hline 1 & Tuntas & 21 & $53,8 \%$ \\
\hline 2 & Tidak tuntas & 18 & $48,7 \%$ \\
\hline
\end{tabular}

Berdasarkan Tabel 3, ketuntasan hasil belajar siswa pada proses pembelajaran mencapai $53,8 \%$. Hal ini menunjukkan bahwa pencapaian ketuntasan belajar siswa belum tercapai yaitu minimal $80 \%$ dari jumlah seluruh siswa dan perolehan nilai minimal 7,00 secara perorangan sehingga perlu dilakukan perbaikan pada siklus berikutnya.

\section{Refleksi}

Pada tahap ini, peneliti bersama guru dan pengamat (teman sejawat) bersama-sama menilai dan mendiskusikan kelemahan-kelemahan yang terdapat pada pelaksanaan tes siklus I yang akan diperbaiki pada siklus II. Pada siklus I ini, penerapan pembelajaran menggunakan pendekatan Open Ended masih belum optimal. Pemantauan guru kurang efektif terhadap kegiatan kelompok sehingga kadang-kadang kelompok yang lebih membutuhkan bimbingan 
merasa kurang diperhatikan. Mengingat masih banyaknya kelemahan yang terjadi pada pelaksanaan tindakan dan hasil belajar matematika pada evaluasi siklus I yang belum memenuhi indikator keberhasilan, maka penelitian dilanjutkan pada tindakan siklus berikutnya dalam upaya meningkatkan hasil belajar dilihat dari kemampuan representasi siswa kelas VIII-A SMP Negeri 9 melalui pembelajaran menggunakan pendekatan Open Ended

\section{Tindakan Siklus II}

\section{Perencanaan}

Berdasarkan hasil observasi, evaluasi dan refleksi pada tindakan siklus I, maka peneliti bersama guru merencanakan tindakan siklus II, agar kekurangan dan kelemahan yang terjadi pada siklus I tidak terulang lagi dan pelaksanaan pembelajaran semakin maksimal. Oleh karena itu, pada tahap perencanaan ini peneliti berkolaborasi dengan guru melakukan hal sebagai berikut:

a. Membuat rencana perbaikan pembelajaran (RPP) untuk tindakan siklus II.

b. Membuat lembar observasi yang ditujukan pada guru dan siswa (aspek yang diobservasi didasarkan pada langkah-langkah pembelajaran pada RPP). Lembar observasi ini nantinya akan digunakan untuk memantau/mengamati kegiatan guru dan siswa selama proses pembelajaran berlangsung.

c. Menyiapkan perangkat evaluasi untuk evaluasi tindakan siklus II.

\section{Pelaksanaan Tindakan}

Pelaksanaan tindakan siklus II terdiri dari dua pertemuan. Peneliti tetap bertindak sebagai pengajar sedangkan Guru bertindak sebagai pengamat (observer). Tindakan pembelajaran siklus II dilaksanakan dalam dua kali pertemuan yaitu pada hari yang sama yaitu hari Rabu tanggal 15 November 2017, namun pada jam yang berbeda yaitu pada pukul 7.20-8.40 WIB dan pukul 13.00-14.25.

Pada kegiatan inti guru meminta siswa duduk bersama kelompoknya. Guru menegaskan jawaban kelompok 1 dengan menggunakan software geogebra sehingga grafik yang dibuat dapat lebih akurat. Pada grafik tersebut menunjukkan adanya titik potong antara persamaan 1 dan persamaan 2 pada titik $(2,0)$ sehingga siswa menyimpulkan bahwa suatu sistem persamaan linear dua variabel akan memiliki suatu penyelesaian ketika kedua persamaan tersebut mempunyai titik potong.

\section{Observasi}

Hasil observasi terhadap guru dan siswa ditunjukkan pada tabel berikut ini: 
Tabel 4. Hasil Analisis Observasi Aktivitas Guru pada Pembelajaran Siklus II

\begin{tabular}{|c|c|c|c|c|}
\hline \multirow[b]{2}{*}{ No } & \multirow[b]{2}{*}{ Aspek } & \multicolumn{2}{|c|}{ Hasil Skor } & \multirow[b]{2}{*}{ Rata-rata } \\
\hline & & $\begin{array}{l}\text { Pertemuan } \\
\quad 1\end{array}$ & $\begin{array}{l}\text { Pertemuan } \\
\quad 2\end{array}$ & \\
\hline \multicolumn{5}{|c|}{ Pendahuluan } \\
\hline 1 & $\begin{array}{l}\text { Guru menyampaikan tujuan } \\
\text { pembelajaran }\end{array}$ & 5 & 5 & 5 \\
\hline 2 & Guru memotivasi siswa & 5 & 5 & 5 \\
\hline 3 & Guru mengadakan apersepsi & 5 & 5 & 5 \\
\hline 4 & $\begin{array}{l}\text { Guru mengondisikan siswa untuk siap } \\
\text { belajar }\end{array}$ & 5 & 5 & 5 \\
\hline \multicolumn{5}{|c|}{ Kegiatan Inti } \\
\hline 5 & $\begin{array}{l}\text { Guru membagi siswa dalam beberapa } \\
\text { kelompok }\end{array}$ & 5 & 5 & 5 \\
\hline 6 & $\begin{array}{l}\text { Guru membagikan LKS kepada } \\
\text { masing-masing kelompok }\end{array}$ & 5 & 5 & 5 \\
\hline 7 & $\begin{array}{l}\text { Guru membimbing siswa dalam } \\
\text { mengerjakan LKS }\end{array}$ & 4 & 5 & 4,5 \\
\hline 8 & $\begin{array}{l}\text { Guru meminta perwakilan kelompok } \\
\text { untuk presentasikan hasil kerja }\end{array}$ & 4 & 5 & 4,5 \\
\hline 9 & $\begin{array}{l}\text { guru meminta perwakilan kelompok } \\
\text { menyelesaikan soal latihan sebagai } \\
\text { langkah mempresentasikan soal ke } \\
\text { dalam bentuk tabel. }\end{array}$ & 5 & 5 & 5 \\
\hline 10 & $\begin{array}{l}\text { Guru memberikan penghargaan kepada } \\
\text { kelompok yang preseentasi dengan } \\
\text { baik. }\end{array}$ & 5 & 5 & 5 \\
\hline \multicolumn{5}{|c|}{ Kegiatan Penutup } \\
\hline 11 & $\begin{array}{l}\text { Guru membimbing siswa untuk } \\
\text { menyimpulkan materi yang telah } \\
\text { dipelajari }\end{array}$ & 4 & 5 & 4,5 \\
\hline 12 & $\begin{array}{l}\text { Guru memberikan tugas rumah dan } \\
\text { mengarahkan siswa untuk } \\
\text { menyelesaikan soal berdasarkan } \\
\text { langkah-langkah yang telah dipelajari. }\end{array}$ & 5 & 4 & 4,5 \\
\hline & $\begin{array}{c}\text { Jumlah } \\
\text { Presentase }\end{array}$ & & & $\begin{array}{c}58 \\
97 \%\end{array}$ \\
\hline
\end{tabular}

Berdasarkan Tabel 4, ketuntasan hasil observasi aktivitas guru pada proses pembelajaran mencapai $97 \%$. Hasil observasi kemampuan guru mengelola pembelajaran ini meningkat sebesar 32\% dari siklus I. Sementara itu, hasil observasi terhadap siswa menunjukkan hal-hal sebagai berikut:

a. Siswa sudah mampu bekerja secara berkelompok.

b. Siswa dalam kelompok mampu mengikuti pembelajaran dengan baik dan menyenangkan.

c. Minat siswa dalam belajar meningkat dengan bantuan software geogebra. 
d. Siswa senang belajar dalam kelompok dan berperan aktif dalam mengkomunikasikan setiap hasil kerjanya kepada teman yang lain

Tabel 5 Hasil Analisis Observasi Aktivitas Siswa pada Pembelajaran Siklus II

\begin{tabular}{|c|c|c|c|c|}
\hline \multirow[b]{2}{*}{ No } & \multirow[b]{2}{*}{ Aspek yang Dinilai } & \multicolumn{2}{|c|}{ Hasil Skor } & \multirow[b]{2}{*}{$\begin{array}{c}\text { Rata- } \\
\text { rata }\end{array}$} \\
\hline & & $\begin{array}{c}\text { Pertemuan } \\
1\end{array}$ & $\begin{array}{l}\text { Pertemuan } \\
2\end{array}$ & \\
\hline 1 & $\begin{array}{l}\text { Siswa mendengarkan dan memberikan } \\
\text { perhatian penuh pada penjelasan materi dan } \\
\text { tujuan pembelajaran }\end{array}$ & 5 & 5 & 5 \\
\hline 2 & $\begin{array}{l}\text { Siswa memperhatikan guru dalam } \\
\text { memberikan motivasi. }\end{array}$ & 5 & 5 & 5 \\
\hline 3 & $\begin{array}{l}\text { Siswa aktif memberikan respon dalam } \\
\text { kegiatan apersepsi }\end{array}$ & 5 & 5 & 5 \\
\hline 4 & $\begin{array}{l}\text { Siswa aktif dalam kelompok ketika } \\
\text { menyelesaikan soal LKS }\end{array}$ & 4 & 5 & 4,5 \\
\hline 5 & Beberapa siswa senang belajar kelompok & 5 & 5 & 5 \\
\hline 6 & $\begin{array}{l}\text { Siswa mampu mengungkapkan pemikiran } \\
\text { tentang materi yang yang dipelajari. }\end{array}$ & 4 & 4 & 4 \\
\hline 7 & $\begin{array}{l}\text { Siswa dalam kelompok mampu } \\
\text { mempresentasikan hasil diskusi di depan } \\
\text { kelas }\end{array}$ & 5 & 5 & 5 \\
\hline 8 & $\begin{array}{l}\text { Siswa di kelompok lain aktif menanggapi } \\
\text { hasil pekerjaan temannya }\end{array}$ & 5 & 4 & 4,5 \\
\hline 9 & $\begin{array}{l}\text { Siswa mampu bertanya ketika mendapat } \\
\text { kesulitan }\end{array}$ & 4 & 5 & 4,5 \\
\hline 10 & $\begin{array}{l}\text { Dengan bimbingan guru, siswa } \\
\text { menyimpulkan pembelajaran }\end{array}$ & 5 & 5 & 5 \\
\hline & $\begin{array}{c}\text { Jumlah } \\
\text { Presentase }\end{array}$ & & & $\begin{array}{l}47,5 \\
95 \%\end{array}$ \\
\hline
\end{tabular}

Berdasarkan Tabel 5, ketuntasan hasil observasi aktivitas siswa pada proses pembelajaran mencapai 95\%. Hasil observasi siswa ini meningkat sebesar 32\% dari siklus I Hal ini menunjukkan bahwa indikator kerja dari segi proses sudah tercapai yaitu minimal $80 \%$ proses pelaksanaan tindakan dilaksanakan sesuai dengan rencana pelaksanaan pembelajaran yang ditetapkan.

\section{Evaluasi}

Pada siklus II ini, pembelajaran dilakukan selama 2 pertemuan untuk menyelesaikan kompetensi dasar "menyelesaikan sistem persamaan linear dua variabel" dan "menyelesaikan soal sistem persamaan linear dua variabel dengan mengaitkan dengan kehidupan sehari-hari". Rangkaian selanjutnya pada tindakan ini adalah memberikan evaluasi atau tes siklus II secara perorangan, yang dilaksanakan pada hari Rabu, 22 November 2017 setelah jam istirahat yaitu pukul 10.00 WIB. Tes ini bertujuan untuk mengetahui apakah terdapat kemajuan kemampuan representasi siswa dari siklus I atau tidak setelah menggunakan pendekatan kontekstual berbantuan software geogebra. 
Tabel 6 Hasil Analisis Ketuntasan Belajar pada Pembelajaran Siklus I

\begin{tabular}{cccc}
\hline No & Ketuntasan & Jumlah & Presentase \\
\hline 1 & Tuntas & 28 & $82,4 \%$ \\
\hline 2 & Tidak tuntas & 6 & $17,6 \%$ \\
\hline
\end{tabular}

Berdasarkan Tabel 6, hasil evaluasi siklus II menunjukan bahwa hasil belajar melalui pengamatan kemampuan pemecahan Masalah siswa mengalami peningkatan dari evaluasi siklus I, siswa yang memenuhi ketuntasan belajar sebanyak 28 siswa 82,4\% (memperoleh nilai > 70). Sedangkan ada 6 siswa atau 17,6\% yang belum memenuhi ketuntasan belajar dilihat dari kemampuan representasi siswa.

Dari pengamatan yang dilakukan peneliti, keberhasilan hasil pelaksanaan tindakan siklus II dapat dilihat dua segi yaitu: Pertama, dari segi proses: pelaksanaan rencana pelaksanaan pembelajaran oleh guru telah mencapai indikator lebih dari 80\%. Kedua, dari segi hasil secara perorangan telah mencapai indikator yang ditetapkan yakni telah mencapai $80 \%$ siswa memperoleh nilai lebih dari 70. Mengacu pada indikator kerja penelitian ini, dapat disimpulkan sudah tercapai.

\section{Refleksi}

Kegiatan refleksi pada siklus II menunjukan bahwa siswa semakin aktif mengemukakakn pendapat, menyelesaikan tugas.sehinngga secara umum kekurangn pada siklus I telah di perbaiaki pada siklus II. Dari pengamatan yang dilakukan guru dan teman sejawat, hasil pelaksanaan siklus II dapat dilihat dari dua segi: pertama dari segi proses: pelaksanaan rencana pembelajaran yang dilakukan guru telah memperoleh hasil $97 \%$ dan tindakan siswa memperoleh hasil 95\%. Hal tersebut telah mencapat dari indikator kerja yaitu tindakan guru dan siswa mencapai $80 \%$ sesuai dengan rencana pelaksanaan pembelajaran. Kemudian, yang kedua dalam segi hasil: hasil belajar siswa pada siklus II mencapai $82,4 \%$ siswa yang mendapatkan nilai minimal 7.00 secara perorangan. Mengacu pada indikator kerja penelitian ini dapat disimpulkan sudah tercapai. Sehingga penelitian ini dilaksanakan sampai pada siklus II. Dengan demikian hipotesis tindakan penelitian ini telah tercapai bahwa kemampuan representasi siswa kelas VIII-A SMP Negeri 9 Cimahi dalam materi persamaan linear dua variabel dapat ditingkatkan dengan menggunakan pendekatan Open Ended.

\section{Pembahasan}

Berdasarkan hasil observasi pelaksanaan pembelajaran matematika pada materi persamaan linear dua variabel untuk siklus I, menunjukkan bahwa penerapan pembelajaran menggunakaan penerapan pendekatan Open Ended 1 merupakan hal yang baru bagi siswa, berdasarkan hasil observasi peneliti menilai siswa belum dapat memahami betul tujuan pembelajaran secara berkelompok yang mengutamakan bekerjasama dalam tim, keterbukaan dalam menyatukan ide-ide atau pemikiran anggota kelompok, kemauan berperan serta untuk lebih aktif dalam kelompok. Pemantauan guru kurang efektif terhadap kegiatan kelompok sehingga kadang-kadang kelompok yang lebih membutuhkan bimbingan merasa kurang diperhatikan.

Hasil tes siklus I menunjukkan bahwa hasil belajar yang diperoleh siswa mencapai 53,8\% atau 21 orang siswa yang mampu mendapat nilai tes minimal 7.00. Hal ini menunjukkan bahwa hasil evaluasi yang diperoleh siswa belum mencapai indikator kerja yang ditetapkan. 
Ada beberapa hal yang menyebabkan tidak tercapainya hasil belajar siswa yaitu tindakan guru dan siswa pada siklus I memperoleh $65 \%$ dan $63 \%$. Hal tersebut belum mencapai indikator kerja yaitu $80 \%$ tindakan guru dan siswa sesuai dengan rencana pembelajaran.

\section{KESIMPULAN}

Berdasarkan hasil analisis dan pembahasan, maka dapat disimpulkan bahwa kemampuan Pemecahan Masalah pada materi "persamaan linear dua variabel" kelas VIII-A SMP Negeri 9 Cimahi dapat ditingkatkan melalui pendekatan Open Ended yang telah dimilikinya serta siswa mampu belajar dalam kelompok yang memiliki kemampuan yang heterogen.

\section{DAFTAR PUSTAKA}

Anisa, W. N. (2014). Peningkatan Kemampuan Pemecahan Masalah Matematik Melalui Pembelajaran Pendidikan Metematika Realistik untuk Siswa SMP Negerti Kabupaten Garut. Jurnal Pendidikan, 1.

Fauziah, A. (2010). Peningkatan Kemampuan Pemahaman Dan Pemecahan Masalah Matematik Siswa Smp Melalui Strategi React. Forum Kependidikan, 30(1994), 1-13.

Hendriana, H., Rohaeti, E. E., \& Sumarmo, U. (2017). Hard Skill dan Soft Skill Matematik Siswa. Bandung: PT. Refika Aditama.

Hidayat, W., \& Sariningsih, R. (2018). Kemampuan Pemecahan Masalah Matematis dan Adversity Quotient Siswa SMP Melalui Pembelajaran Open Ended. JNPM (Jurnal Nasional Pendidikan Matematika), 2(1), 109-118.

Mulhamah, \& Putrawangsa, S. (2016). Penerapan Pembelajaran Kontekstual dalam Peningkatan Kemampuan Pemecahan Masalah Matematika. Jurnal Pendidikan Matematika, 1 . 
280 Mulyowati, Afrilianto, \& Rohaeti, Kemampuan Pemecahan Masalah Matematis Siswa ... 